Routledge International Studies in the Philosophy of Education

\title{
MEDIA AND MORAL EDUCATION
}

\section{A PHILOSOPHY OF CRITICAL ENGAGEMENT}

\author{
Laura D’Olimpio
}

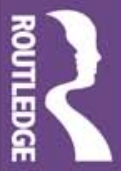




\section{Media and Moral Education}

Media and Moral Education demonstrates that the study of philosophy can be used to enhance critical thinking skills, which are sorely needed in today's technological age. It addresses the current oversight of the educational environment not keeping pace with rapid advances in technology, despite the fact that educating students to engage critically and compassionately with others via online media is of the utmost importance.

D'Olimpio claims that philosophical thinking skills support the adoption of an attitude she calls critical perspectivism, which she applies in the book to international multimedia examples. The author also suggests that the Community of Inquiry - a pedagogy practised by advocates of Philosophy for Children - creates a space in which participants can practise being critically perspectival, and can be conducted with all age levels in a classroom or public setting, making it beneficial in shaping democratic and discerning citizens.

This book will be of interest to academics, researchers and postgraduate students in the areas of philosophy of education, philosophy, education, critical theory and communication, film and media studies.

Dr Laura D'Olimpio is a Senior Lecturer in Philosophy at the University of Notre Dame Australia. 


\section{Routledge International Studies in the Philosophy of Education}

For more titles in the series, please visit www.routledge.com/Routledge-InternationalStudies-in-the-Philosophy-of-Education/book-series/SE0237

\section{Media and Moral Education}

A Philosophy of Critical Engagement

Laura D'Olimpio

Philosophy, Dialogue, and Education

Nine Modern European Philosophers

Alexandre Guilherme and W. John Morgan

Heidegger During the Turn

Poetry, Literature, and Education

James M. Magrini and Elias Schwieler

In Community of Inquiry with Ann Margaret Sharp

Childhood, Philosophy and Education

Edited by Megan Jane Laverty and Maughn Rollins Gregory

\section{Technologies of Being in Martin Heidegger}

Nearness, Metaphor and the Question of Education in Digital Times

Anna Kouppanou

Creating the Practical Man of Modernity

The Reception of John Dewey's Pedagogy in Mexico

Victor J. Rodriguez

Reinventing Intercultural Education

A Metaphysical Manifest for Rethinking Cultural Diversity

Neal Dreamson

Teachability and Learnability

Can Thinking Be Taught?

Paul Fairfield

Neuroscience and Education

A Philosophical Appraisal

Edited by Clarence W. Joldersma 


\title{
Media and Moral Education A Philosophy of Critical Engagement
}

\section{Laura D’Olimpio}

\author{
Routledge \\ 甭 Taylor \& Francis Group


First published 2018

by Routledge

2 Park Square, Milton Park, Abingdon, Oxon OXI4 4RN

and by Routledge

711 Third Avenue, New York, NY 10017

Routledge is an imprint of the Taylor o Francis Group, an informa business

\section{(C) 2018 Laura D’Olimpio}

The right of Laura D'Olimpio to be identified as author of this work has been asserted by her in accordance with sections 77 and 78 of the Copyright, Designs and Patents Act 1988.

All rights reserved. No part of this book may be reprinted or reproduced or utilised in any form or by any electronic, mechanical, or other means, now known or hereafter invented, including photocopying and recording, or in any information storage or retrieval system, without permission in writing from the publishers.

Trademark notice: Product or corporate names may be trademarks or registered trademarks, and are used only for identification and explanation without intent to infringe.

British Library Cataloguing-in-Publication Data

A catalogue record for this book is available from the British Library

Library of Congress Cataloging-in-Publication Data

A catalog record for this book has been requested

ISBN: 978-1-138-29142-3 (hbk)

ISBN: 978-1-315-26545-2 (ebk)

Typeset in Galliard

by Apex CoVantage, LLC 
For all the teachers, past, present, and future. 

Taylor \& Francis http://taylorandfrancis.com 


\section{Contents}

Acknowledgements viii

Introduction 1

$\begin{array}{lll}\text { l Critical perspectivism } & 18\end{array}$

2 Compassionate engagement 35

3 Critical engagement 53

4 Social media and multiliteracies $\quad 76$

$5 \quad$ Teaching critical perspectivism 93

6 Philosophy in the public sphere 109

$\begin{array}{ll}\text { Index } & 123\end{array}$ 


\section{Acknowledgements}

I am grateful to my family, friends, students and colleagues for their encouragement and support of my work on this book. In particular I would like to thank Michael Hand, Andrew Peterson, Michael Levine and Christoph Teschers for reading and providing feedback on draft versions of my proposal and chapters and for spotting my occasionally hilarious typos. Without these exchanges with friends and mentors, the ideas in this book would surely have been expressed in a less refined manner. I am also grateful to my peers within the philosophy for children and philosophy of education communities. Your enthusiasm for teaching young people critical thinking skills and the role philosophy has to play in improving society constantly inspires me and makes me happy to be working in this area. Conversations with my peers within the Association for Philosophy in Schools (APIS, WA), the Federation of Australasian Philosophy in Schools Associations (FAPSA) and the Philosophy of Education Society of Australasia (PESA), as well as attendance at their conferences and workshops, have all been rewarding and a good testing ground for my ideas in their various stages of development. Thanks to the University of Notre Dame Australia, which has helped fund my attendance at these conferences. Thanks also to Routledge for their editorial support. Last but not least, thank you to my husband for his loving support and many cups of tea. 


\section{Introduction}

Critical thinking skills are sorely needed in contemporary society, with its focus on knowledge, technology and connectedness. As global citizens, we receive more information and images than ever previously, thanks to our technological devices, the Internet and the plethora of online sharing platforms. When it comes to mass art and social media, we need to discern between reliable sources of information, misinformation, hoaxes, scams and fake news. The discerning citizen will be able to engage critically, creatively, collaboratively and compassionately with multiple sources and diverse perspectives encountered on a daily basis.

In our contemporary world, teaching people to engage critically and compassionately with others via online media is of vital importance. Educational environments such as schools have struggled to keep up with rapid advancements in technology. Moral agents use rational emotions such as compassion to imagine 'what it is like' for others prior to deciding how they should act. Social media allows us to engage imaginatively with stories of diverse others globally. Teaching transferable skills such as critical thinking and moral engagement through the study of philosophy is one way that moral education may occur, allowing students to apply these skills online.

It is important that we educate people to be able to think for themselves. Adopting a democratic and inclusive attitude, a discerning citizen will encourage conversations that seek to dispel ignorance, recognising pluralism but rejecting relativism. Relativists believe that the truth, or moral truth, is completely subjective and relative either to the individual (known as subjectivism) or to a cultural group (cultural relativism). The problem with this position is that it does not allow for shared moral values or objective truth and it implies that all opinions are of equal value (whether that refers to truth or moral value). However, even where there are individual and cultural differences, there are also shared human values and discoverable truths we are justified in believing. In seeking to be ethically engaged, the moral agent will critically and compassionately investigate claims and assumptions, stereotypes and values conveyed by multimedia sources. As such sources are commonplace, we should embrace them and engage with them appropriately. For these reasons and more, it will also become obvious that philosophers have an important role to play within both educative settings and public spaces. 


\section{Introduction}

In this book, I have two main aims. Firstly, to detail and defend a particular moral attitude that should be adopted when engaging with multiple sources of information, particularly information received via technological media. I call this attitude 'critical perspectivism'. Critical perspectivism gives us the ability to engage with multiple perspectives in a critical, yet compassionate, manner. This approach is holistic and pragmatic in that it assumes that people are rational as well as affective creatures, situated in a context. In order to be engaged in a critically perspectival manner, one must be educated to be critical, compassionate and collaborative in one's approach to learning, receiving and transmitting information. My second main aim is to explain how we may teach people to be critically perspectival and encourage them to adopt this attitude. After introducing the concept and explaining why I believe that critical perspectivism is necessary in today's global, technological world, I will argue that this mode of attention can be modelled, taught and practised in order to form a habit. Such practise may take place within a classroom setting, or in a forum where public philosophy is being offered, for instance in a philosophy café that employs a method of Socratic dialogue. These examples will be fleshed out further in the book, but it will become apparent that critical perspectivism sees philosophy as a praxis, and the work of the philosopher as educator or public intellectual can complement and supplement the valuable work of philosophy in the academy.

In order to illustrate my second main claim, I will show how critical perspectivism may be cultivated by the philosophy in schools or philosophy for children (P4C) pedagogy, which includes the community of inquiry (CoI) methodology. In an educational context, there is an increasing awareness of the need to prepare students not simply for exams but also for life. When it comes to educational institutions, which specialise in the production of knowledge, we should include the study of philosophy into the curriculum. Philosophy teaches critical thinking skills that are required for children to become informed, socially situated learners (Millett \& Tapper, 2012; Golding, Gurr \& Hinton, 2012; Burgh, Field \& Freakley, 2006; Lipman, 2003; Splitter \& Sharp, 1995). I will focus on the knower who possesses the intellectual virtue of discernment and claim that the CoI method as practised by proponents of $\mathrm{P} 4 \mathrm{C}$ is a useful tool by which to develop and encourage critical, caring, creative and collaborative thinking skills that can be applied to engagement with everyday moral dilemmas, mass art and social media.

When referring to social media, the definition given by Boyd and Ellison (2008, p. 211) will prove useful:

We define social network sites as web-based services that allow individuals to (1) construct a public or semi-public profile within a bounded system, (2) articulate a list of other users with whom they share a connection, and (3) view and traverse their list of connections and those made by others within the system.

So why is this so important? Why do we need to teach people how to engage respectfully but also critically with online information and virtual others? 
Technological advancements have ushered in an age whereby the way social media and the Internet are used has changed our lives, including the way we seek out information, the way we spend our leisure time and how we communicate with one another. The vast majority (92\%) of American teenagers use social media daily, aided by the widespread availability of smart phones (Lenhart, 2015). In Australia, $79 \%$ of people access the Internet daily and $68 \%$ of Internet users have a social media profile, with the majority of them (70\%) accessing social media via a smartphone and using an application (app) (Sensis, 2015). Significantly, most of these young people learn how to use technology and social network sites informally, through their engagement with such sites and from their peers, rather than from their parents or teachers.

Young people today are referred to as digital natives, meaning that they have only ever known a time when the Internet existed and they have grown up with this technology. The advent of Web 2.0 (replacing the WWW or World Wide Web, which is retrospectively called Web 1.0) was heralded as liberating and is characterised by increased participation as pervasive network connectivity and communication channels encourage greater use and collaboration. However, although young people are growing up with the Internet, this does not mean they are born with skills to use it in a savvy and safe or even respectful manner. Such skills, or multiliteracies as I refer to them, must still be learned. Today's Web 2.0 allows for the democratisation of the Internet, as users include individuals as well as groups, institutions, companies and governments. Such accessibility has supported and, in turn, been supported by neoliberal policies which advocate corporate deregulation, privatisation, competition, entrepreneurialism and open markets to achieve both financial success and individual self-actualisation. "While these policies have met with global protests, they have become the predominant paradigm of the twenty-first century" (Marwick, 2013, p. 11).

In this brave new world, famous personalities can reveal immediate and intimate insights into their lives, companies can advertise directly to their market consumer base and expand their brand globally in a short space of time, clients and customers have immediate access to space to voice their praise or frustration at products, services, and their voices are heard and may be responded to immediately. The number of voices are staggering. Users (of all kinds and affiliations) have the chance to alter and impact upon the Internet and its information contained therein, which is updated and changed in real time. The social nature of Web 2.0 differentiates it from the static WWW that went before. Web 2.0 also allows social media companies to have a lot of power and even more profit (Marwick, 2013, p. 4) as they use, and often struggle to keep up with, social platforms that include wikis, social networking, social bookmarking, forums, blogs, applications and interactive websites.

Meanwhile, it is the technology industry that benefits financially, as consumers laud the products produced at a rapid rate. In the US, this industry has remained profitable in an otherwise difficult economy with venture capital funding in San Francisco, 'the centre of the social media world' and home of Google, Facebook and Twitter, increasing between 2007-2011 despite the economic downturn (Marwick, 2013, pp. 3-4). The profitability of the technology industry and the 


\section{Introduction}

desire of consumers for new gadgets show no signs of abating. In tension with the enthusiasm for what new technology can do for us is a worry about what such technology is doing to us. Researchers worry about increased levels of narcissism, anxiety about online bullying, decreased attention spans, antisocial behaviour including the recruitment of vulnerable youths to extremist military organisations, cyber terrorism and the propagation of misinformation, hoaxes and scams.

We must ask whether or not such fears are well founded or if these risks are any higher than they have previously been. The risks present in today's technological society may take a different form and are able to manifest in a new way due to the technology available, but this alone does not prove that we should be more alert and alarmed than usual. However, it does mean that we need to consider the best way to engage online with others and with the information we receive. A particular focus of moral concern is on the young and what can be done to protect them online.

It is important to point out that the online world is just as real as the ordinary world. This is not a make-believe world such as that you may encounter in a fictional narrative. There may be virtual and fictional aspects to the online world, such as avatars through which one portrays oneself, and our ability to do certain things is different in virtual space. Obviously one's embodiment alters as the body we use online is decontextualised and nonphysical. Yet there are real others with whom one interacts, whether they be people users know in real life and have met face-to-face or not. Ultimately, it will be critical thinking skills such as rational discernment and the moral attitude of compassion that is contextually applied that will best serve users, young and not-so-young, of social media. Pragmatically, such transferable thinking skills serve us well in life, and these skills may be applied online. A good way of educating such critical thinking skills and moral dispositions is through the study of philosophy, particularly through methodologies used by $\mathrm{P} 4 \mathrm{C}$ practitioners. Thus, the study of philosophy may prove useful in assisting students to learn how to effectively engage with technologically mediated sources of information that are ubiquitous in the twenty-first century.

\section{Critical perspectivism}

My first chapter will be dedicated to detailing critical perspectivism, a moral attitude that may be practised and adopted when engaging with multiple sources of information. It is an attitude that supports a practise of being morally engaged in the world by processing and understanding information received from massproduced and distributed media sources in a critical and compassionate manner. Much of the information (including images) we encounter contains implicit or explicit social, political and moral messages that need to be approached actively and critically with a caring response to real-life others. As technology increases the rate and amount of information we receive, we must seek to morally evaluate and assimilate useful information, while discarding misinformation, and avoiding hoaxes and scams. 
Critical perspectivism has two central features: it is compassionate and it is critical. In chapters two and three, I will examine each of these features in turn, considering the role they play in our responses to people and mediated information, with the aim of seeking knowledge, wisdom and ethical relationships.

\section{Compassion}

Chapter two focusses on how ethical agents engage in a compassionate and imaginative manner with others, drawing upon the moral philosophy of contemporary virtue ethicist Martha Nussbaum. Nussbaum explores and defends the rational emotion of compassion as a moral or 'loving' attitude. She claims that this loving attitude may be practised in response to narrative artworks, which may assist in the moral education of readers. Thus, Nussbaum (1987) claims that moral philosophy would be improved by the addition of aesthetically and ethically good narrative artworks that provide readers with the opportunity to practise ethical decision-making skills. Adopting a framework of virtue ethics, Nussbaum makes a teleological claim that good art aids moral education. People who engage with such works have the opportunity to practise their ethical responses to life-like situations depicted in works of fiction. Such practise encourages the use of their moral imagination in a positive manner in everyday life.

In her later writings, Nussbaum $(1995$, p. 6) extends her theory to include film as an example of narrative art. If Nussbaum is correct, the potential exists for mass artworks, such as films, to be used to illuminate moral dilemmas for the viewer, as narrative artworks allow for the realistic and nuanced portrayal of life. It may be that we can learn from the diverse perspectives offered to us via mass art and social media, although the technological features of such media will have to be carefully considered and critiqued. I will critically investigate Nussbaum's notion of an ethical mode of attention and consider whether this argument could be extended to mass art and social media. My main focus is on whether Nussbaum's loving and compassionate attitude as a moral attitude to be adopted towards others is adequate for those engaging with mass information and multimedia sources.

I am sympathetic to the idea that, by practicing what Nussbaum calls a 'loving attitude', her version of ethical attention, we can form virtuous habits that lead to phronesis (practical wisdom). However, my worry is that if we over-emphasise the affective component of compassion, we may forget to be critical and apply the appropriate amount of distance between ourselves and those who suffer, thereby rendering our ethical engagement with them biased and emotive rather than rational. In an Aristotelian sense, we must find the golden mean for our actions to be considered virtuous. Furthermore, in our contemporary, technological society with multiple perspectives constantly bombarding us, there is a need to maintain a healthy dose of critical distance and scepticism even while remaining compassionate to the suffering of real-life others. Thus, I defend critical perspectivism as an enhanced moral attitude that encourages moral agents to critically evaluate 
information and figure out the appropriately rational and compassionate response to people and situations, while seeking appropriate evidence for their beliefs.

\section{The moral possibilities of mass art and media}

After granting that compassion is an important part of a moral attitude one should adopt when seeking to make ethical decisions, chapter three further explores why a moral agent must be critical and cautious when negotiating technologically mediated sources of information. To this end, chapter three sets the scene by engaging with the approaches taken towards mass art within the field of philosophical aesthetics. Historically, philosophers in the Anglo-American, typically analytic, tradition have been very resistant to including mass-produced and distributed artworks into the category of art qua Art proper. Theorists such as R. G. Collingwood (1938), Dwight MacDonald (1963), Clement Greenberg (1971), T. W. Adorno and Max Horkheimer (1997) have worried that mass art is pseudo art and encourages passive spectatorship. The interesting aspect to this seemingly elitist critique is the moral concern that appears to underlie their theories. By excluding, for example, film from the category of art due to its technical means of production (and reproduction), these theorists demonise the medium and mistakenly consider all mass art to be bad, both ethically as well as aesthetically.

Times have changed, and many contemporary philosophers now embrace mass art and film as art and as vehicles for the portrayal and exploration of philosophical ideas. Theorists such as Walter Benjamin (1969), Gilles Deleuze (1986; 1989), Thomas Wartenberg (2007), Stephen Mulhall (2002) and Daniel Frampton (2006) embrace 'filmosophy' and celebrate, in particular, the work of film auteurs. This positive reaction to film sees mass art as able to abet active and critically engaged spectatorship, and includes the possibility of philosophical learning via watching and engaging with (certain) films. When it comes to films, I claim that we need to consider what the masses are watching alongside what can be achieved with mass art and, as such, I argue for a moderate approach to mass art (D'Olimpio, 2014). This moderate approach entails taking seriously the ethical concerns of those traditional theorists who were pessimistic about the effects of mass art and also embraces the optimistic perspective that mass art may encourage critical spectatorship and transmit philosophical ideas in an exciting manner to large audiences.

The reason I adopt this moderate approach is because I am interested in the educative potential of technologically produced and distributed works. The focus of our discussion should be on the critical thinker who is receiving, engaging with and possibly transmitting the work and/or its message to others. This is where the attitude of critical perspectivism is of vital importance. In considering how spectators read such stories, we can extend this critique to other social media forms and consider how users of social media may also be able to engage critically and empathetically with one another and with the stories of diverse others.

In our global, technologically connected world, the key skill of multiliteracies (Cope \& Kalantzis, 2000) is gaining prominence. As technology changes 
so quickly, I believe the sensible thing to do is to educate citizens to be critical, compassionate and collaborative as well as creative in their approach to what they see and hear. This way, even as the mediums alter in ways we could not hope to foresee or imagine, people will be able to ask not just 'what', 'how' and 'where' but also 'why'. The 'why' questions are of paramount importance, as they include moral questions such as 'should we . ..'? Thus, chapter three details the approach to mass art that has changed over time, as technology becomes increasingly a part of our everyday lives and takes seriously the ethical as well as the aesthetic concerns of philosophers who recognise the power of social media, images, film and television in society.

Any account of the role mass art may play in society must take into account the concerns theorists such as Adorno and Horkheimer (1997) outline with regard to the dominance of mass cultural works that promote a passive audience response. One reason mass art succumbs to aesthetic and ethical criticism has to do with its production and consumption within a market of monopoly capitalism. Moral dilemmas associated with mass cultural products that aim to achieve economic as opposed to aesthetic ends, although not inherent in the medium or production methods itself, are a factor of which consumers and artists should be aware. Pro-mass art theorists such as Walter Benjamin (1969) need to consider how mass artworks may combat the promotion of a non-reflective, passive audience response that encourages viewers to 'switch off' their critical voice.

Much like my approach to the narrative artworks used as examples in chapter two, I do not see any point in labelling all artworks of a certain form 'good' or 'bad' based solely on their uniqueness or accessibility, their mass production or consumption, or their formal features, even where such features may incline artworks and mass-produced and distributed products to be better or worse (aesthetically and/or ethically). My focus remains on the attitude of the viewer engaging with and receiving such works along with the messages contained therein. While I argue that artists and technicians and users of technology also have an ethical obligation to create and use such works and media in ethical ways, I am focussed on the ethical attitude of critical perspectivism that may be taught, exemplified and practised. Critical perspectivism is a moral attitude that may be applied to multiple sources of information and media that we encounter every day. In this way it is holistic and pragmatic and demands that moral agents be critically as well as compassionately engaged with the world.

\section{Multiliteracies}

Chapter four focusses on some examples that highlight why it is so important to teach people to adopt an attitude of critical perspectivism. Using three examples of the perils and pitfalls of social media; namely, hoaxes, scams and catfishing, I defend the sentiment echoed by those theorists who speak about multiliteracies. Specifically, "students must be agents of text rather than victims of text, whether that text is printed and found in school or visually digitized and found in the street" (Albers \& Hartse, 2007, p. 7). Society needs critical thinkers who 


\section{Introduction}

are also engaged morally as citizens, people who are compassionate as well as practical.

It is a unique feature of the contemporary world that we have access to more information and images, opinions and various perspectives than ever previously thanks to our global technology and connectivity. As every individual may broadcast their ideas and experiences to everyone else instantaneously, and statements may be fact checked against the truth using evidence, statistics, corroboration etcetera, it seems strangely perverse that the Oxford Dictionary's 2016 word of the year is 'post-truth': an adjective defined as 'relating to or denoting circumstances in which objective facts are less influential in shaping public opinion than appeals to emotion and personal belief.'

The post-truth climate that has now been identified seems to be supported by the proliferation of multiple perspectives available to anyone with Internet access. As users may log on and find a statement, website, or misquote that supports anything they already believe or something they wish or fear to be true, and are able to chat with others with whom they agree, an echo-chamber is set up that reinforces the idea, regardless of its veracity. Further, arguments with others with whom they disagree do not seem to dispel the ignorance, unlike what is aimed for in a Socratic dialogue. Rather, such debate may reinforce the biased or blatantly false view through what behavioural psychologists term the 'familiarity backfire effect' (Cook \& Lewandowsky, 2011). The backfire effect may be seen in relation to the attempt to debunk false views, such as when responding to climate change deniers or anti-vaccination supporters. By mentioning 'climate change science', or by fact checking claims of anti-vaxxers, such attempts serve only to reinforce the myths, with Cook and Lewandowsky noting that "a simple myth is more cognitively attractive than an over-complicated correction" (2011, p. 3 ). Such worrying attitudes towards truth and evidence epitomise how popularity, sensationalism and 'reassuring' myths (it is more reassuring to think that climate change is false) and false beliefs hold much sway and political power in the world today.

This problem of subjectivism is particularly evident online as, with our technological capabilities, we have access to many various ideas through blogs, news websites of varying journalistic quality, satirical websites, self-created and uploaded videos, images and memes, discussion boards and chat applications, not to mention advertisements and predatory messages, all with varying levels of privacy. We seek out information and we stumble across it, and we want people to be able to understand and process what they find. In learning to distinguish between valuable sources of reliable information and the plethora of dross, I argue that the best answer lies not in censorship necessarily, but, rather, in teaching those who engage with such mediums the ability to critically discern between them.

Within the field of educational pedagogy, there is a discussion about the need to educate students in what may be called multiliteracies (Kalantzis \& Cope, 2012) as the need for educational institutions to catch up and keep up with the speed of individual technological literacy is felt. Children today are learning more about literacy outside of school than they are in, especially through electronic 
and digital devices and software. Teachers increasingly need to look critically at the influence of media on in-school and out-of-school literacies, and educational institutions cannot afford to ignore these new media platforms. Technological tools must be embraced if we wish to teach students to engage with them critically as well as creatively. Literacy is reinventing itself, with the advent of new information technologies and the complex multiliteracies allowed by them; but the critical thinking skills required to engage with different texts is the same. After considering some examples of why critical perspectivism is needed for online engagement, chapter five examines how we might teach people to be critically perspectival.

\section{Education}

Chapter five highlights the need to cultivate in children and adults a habit of engaging critically with what they see and hear. Critical perspectivism is necessary in today's world because it gives us the ability to engage with multiple perspectives and still judge: to be critical, caring and compassionate while recognising the context in which dialogue and interactions take place. There are some assumptions embedded in my defence of critical perspectivism, including the fact that human beings are logical/rational and emotional. In a practical, holistic approach, we must focus not only on developing critical thinking skills, but also on appropriately employing and acting upon rational emotions such as compassion. It is the combination of being critical as well as caring that supports a critically perspectival approach to knowledge and to others with whom we interact online or face-to-face. I defend the use of philosophy as a praxis to habituate critical, caring, creative and collaborative citizens who are democratic but also still make normative judgements with respect to what is good. In order to illustrate my arguments, I draw upon P4C and the CoI pedagogy.

Matthew Lipman (2003) started P4C together with Ann Sharp in the 1970s in America, drawing upon the pragmatic philosophy of John Dewey (1997; 2008). Claiming that philosophy need not be confined to universities, Lipman maintained that children could practise critical thinking skills through the use of dialogue and by using specifically written, age-appropriate philosophical narratives as a stimulus text. Lipman defines critical thinking as "thinking that (1) facilitates judgment because it (2) relies on criteria, (3) is self-correcting, and (4) is sensitive to context" (2003, p. 212). By thoughtfully discussing stories that contain philosophical concepts, Lipman hoped to encourage children to ultimately develop into reasonable and democratic citizens. Along with critical thinking skills, Laurance J. Splitter and Ann Sharp (1995) added 'caring' and 'creative' thinking as equally important skills children should be encouraged to develop. Therefore, P4C aims at shaping critical, caring and creative thinkers who are able to work collaboratively as members of a group in search of truth.

One way in which teachers facilitate $\mathrm{P} 4 \mathrm{C}$ in their classroom is through a CoI whereby participants sit in an inward-facing circle to engage in a dialogue based on a particular topic, usually seeking to explore a stimulus question that is open 
and philosophical (Cam, 2006). In order to generate the students' questions, teachers may firstly read a text such as Thinking Stories (Cam, 1993) and facilitate an activity using a Question Quadrant (Cam, 2006). The questions children come up with can be scribed by the teacher on a whiteboard and then voted upon in order to gain a consensus as to which question should be the central focus of the CoI. The CoI is guided by the line of inquiry that develops, and the teacher is a facilitator rather than the one source of 'correct' answers. This radicalises the role of teacher as a member of a community that is thinking alongside children as opposed to simply giving students information that they need to learn and be able to recite (Kennedy, 2015). The CoI takes seriously the idea that children have their own ideas, questions and voices that are worth voicing, listening to and exploring. This challenges the perceived gap between adults and children, creating a space whereby adults can listen carefully for children's wisdom (Vansieleghem \& Kennedy, 2012, p. 5 ).

The aim of the CoI is to encourage children to think for themselves and to learn to trust their own capacity for rationality and prudence. Thinking is thus individual and collective: there is the reflective thinking that is done as an isolated individual and there is also the thinking that is done in a group whereby ideas are built upon communally as well as challenged or questioned. The CoI may assist participants to explore ideas collaboratively and thus grow in self-esteem and confidence as they recognise themselves as one amongst a group of learners. As Splitter (2011, p. 497) explains:

Participating in a CoI allows students, individually and collaboratively, to develop their own ideas and perspectives based on appropriately rigorous modes of thinking and against the background of a thorough understanding and appreciation of those ideas and perspectives that, having stood the test of time, may be represented as society's best view of things to date.

In this way, educators are aiming at deepening children's critical thinking skills as they facilitate a meaningful dialogue that aims at a shared understanding and also at truth. Advocates of $\mathrm{P} 4 \mathrm{C}$ are also concerned with caring, creative and collaborative thinking skills, as students are recognised as seeking truth while being situated in a context, in a time and place. This contextual aspect to our existence does not deny the existence of shared values, and, ultimately, the CoI pursues our best understanding of things as they are currently, while remaining open to selfcorrection with time and as new information comes to light. The CoI follows the line of inquiry where it leads and acknowledges the pursuit of knowledge to be a process that is open, pluralistic and democratic (Winstanley, 2008).

The attitude of critical perspectivism may be educated via the CoI pedagogy and then applied to our online engagement. Our judgements and actions become ingrained the more we practise them. Factors influencing our habitual manner of responding to people and situations come from many sources, including friends, family and the social environment around us. Mass and social media and mass art are prominent sources that depict examples of behaviour that are then judged as 
acceptable or problematic within our society. Such depictions should, according to Nussbaum $(1990 ; 1995)$ and Iris Murdoch (1970), at least in respect to narrative artworks, be truthful and fair. Yet much of our mass art promotes questionable stereotypes and dubious fear-filled stories that are purported to inform us of newsworthy facts. Ultimately, we require the skills to be able to discern fact from fiction, genuine insight from embellishment and manipulation. We similarly require these cognitive abilities and guiding moral principles to be applied when we consider with what we choose to engage, propagate and share. In the age of Web and Media 2.0, everyone is a storyteller with the ability to pitch an idea on the world stage. The CoI is designed to teach us to be critical of the ideas and beliefs we and others hold, while simultaneously being respectful towards and compassionate of the others who hold such diverse perspectives, recognising that together we form a community of people seeking the truth and a harmonious life. For those who do not seek truth or harmony, we must be able to appeal to normative values in order to judge and condemn things that may threaten our peaceful coexistence.

Once taught or modelled, and if practised, eventually a habit may form whereby people routinely engage with multiple perspectives in a critical and compassionate manner. This habit may be formed within a classroom setting or elsewhere, and one methodology by which to achieve it is the CoI. When properly facilitated, the CoI may equally be employed in a philosophy café and thus highlights the way in which public philosophy may be useful within society. Teaching people to be critically yet compassionately engaged citizens who are able to effectively negotiate multiple perspectives is a necessary skill in today's technologically connected, global world. Using philosophy as a praxis highlights the important role philosophers may take in educational as well as public spaces. Approaching philosophy as accessible, making use of ordinary language and taken to the streets, as it were, is not new or radical, yet is vital now more than ever. Furthermore, approaching philosophy in this practical and applied manner does not diminish the serious work of philosophy; nor does it undermine the academic work done in universities within philosophy departments. In fact, the philosopher as public intellectual, serving to model such critical, and, importantly, compassionate thinking skills, can complement and supplement the valuable work of philosophy done in the academy. It is my hope that such an approach would serve academic philosophy well by expanding its vocational application, along with making philosophy more inviting and inclusive, particularly for women and minorities, something the discipline sorely needs.

\section{The stories we tell}

The virtual public sphere is open in an exciting new way with ideas being discussed and debated in a transparent and engaging manner. Yet the openness of the Internet also makes it a public forum that evokes criticism and trolling. The technological tools themselves are value neutral; it is the character that employs them for constructive or destructive means which may be labelled virtuous or 


\section{Introduction}

vicious. Social media and online sites may alter with new technological developments, yet it is the personality of individuals using such mediums that requires the focus of educators. At worst, unstructured discussion online is full of misinformation and promotes superstition and anti-scientism. It may allow for negative personal attacks or bullying. At best, it fosters genuine learning through expansive dialogue that respects those engaging in the discussion and encourages selfreflection. To foster the latter, we must train the habits of the individual, which include critical and creative thinking, the intellectual and moral virtues, discernment and compassion. Instead of dealing with concerns about social networking sites by banning their use, we ought to teach our students to engage critically with information sources so that they have the tools they'll need when out on their own in the technological world, a world that cannot be ignored or avoided without disengaging from society.

In a unique way, consumers are more connected globally and more able to make an impact on the marketplace (of ideas as well as of products and services) than ever before. The notion of consumer satisfaction has gained enormous power, with reviews and 'likes' gaining traction as such feedback has a direct impact upon industry, service providers and public intellectuals. Those using social media have direct access to famous people, experts, institutions and industries and feel empowered in that their voice is instantly heard. In the old days, a grumpy 'letter to the editor' may or may not be published. These days, if that grumpy consumer has access to the Internet, they can make their complaints known far and wide immediately. In a time when nothing is erased, this is both positive and a cause for concern.

In a truly democratic space, the positive uptake of messages such as ethical causes and charitable donations is visible as certain fads go 'viral'. Yet this is also set against the notion of 'slacktivism', which amounts to clicking 'like' on a picture of a starving child to support the cause and raise awareness for a charity, which is not the same thing as donating to assist the charity or the starving children. Raising awareness alone may not translate into ethical behaviour or actions that actually assist and impact positively on a cause. Additionally, in this populist environment, the positive aspect of the client's voice being heard is set against the negativity of the troll's voice being heard and the rise in cyber-bullying.

It appears to me that education and moderated forums can play an important role in dealing with these issues. Issues of unethical behaviour are a human problem, and what we are now seeing is the expression of such antisocial behaviour through technological mediums. An important issue that must be considered by those engaging in a critically perspectival manner (online or elsewhere) is whether or not all opinions are entitled to be heard within a liberal democracy. In chapter six, I consider whether philosophers may encourage critical thinking and compassionate responses beyond the classroom environment, and to that end I examine the role of the philosopher as a public intellectual. It is worth exploring whether philosophical thinking skills can assist to set public debates on the right path via the use of good argumentation and the application of critical thinking skills such as avoiding fallacies and addressing the topic, not the person. In modelling such 


\section{Introduction}

Adorno, T. W. , \& Horkheimer, M. (1997). Dialectic of Enlightenment. London: Verso. Albers, P. , \& Harste, J. C. (2007). The arts, new literacies, and multimodality. English Education, 40(1), 6-20.

Benjamin, W. (1969). The work of art in the age of mechanical reproduction ( H. Zorn , trans.). In H. Arendt (Ed.), Illuminations (pp. 217-252). New York: Schocken Books.

Bleazby, J. (2011). Overcoming relativism and absolutism: Dewey's ideals of truth and meaning in philosophy for children. Educational Philosophy and Theory, 43(5), 453-466.

Boyd, D. , \& Ellison, N. (2008). Social network sites: Definition, history, and scholarship. Journal of Computer-Mediated Communication, 13(1), 210-230.

Burgh, G. , Field, T. , \& Freakley, M. (2006). Ethics and the community of inquiry: Education for deliberative democracy. South Melbourne: Thomson.

Cam, P. (Ed.). (1993/1997). Thinking stories. Alexandria, NSW, Australia: Hale \& Iremonger. Cam, P. (2006). Twenty thinking tools. Camberwell, Victoria, Australia: ACER.

Collingwood, R. G. (1938). The principles of art. Oxford: Clarendon Press.

Cook, J. , \& Lewandowsky, S. (2011). The debunking handbook. St. Lucia, Australia: The University of Queensland. November 5. ISBN 978-0-646-56812-6. Retrieved from http://sks.to/debunk

Cope, B. , \& Kalantzis, M. (Eds.). (2000). Multiliteracies: Literacy learning and the design of social futures. London: Routledge.

Deleuze, G. (1986). Cinema I: The movement-image ( H. Tomlinson \& B. Habberjam , trans.). Minneapolis: University of Minnesota Press.

Deleuze, G. (1989). Cinema II: The time-image. Minneapolis: University of Minnesota Press. Dewey, J. (1997). How we think. Mineola, NY: Dover Publications.

Dewey, J. (2008). Democracy and education, 1916. Studies in Education, 5(1/2), 87-95.

D'Olimpio, L. (2014). Thoughts on film: Critically engaging with both Adorno and Benjamin.

Educational Philosophy and Theory, 47(6), 622-637.

Frampton, D. (2006). Filmosophy. London: Wallflower Press.

Golding, C. (2011). The many faces of constructivist discussion. Educational Philosophy and Theory, 43(5), 467-483.

Golding, C. , Gurr, D. , \& Hinton, L. (2012). Leadership for creating a thinking school at Buranda State School. Leading \& Managing, 18(1), 91-106.

Greenberg, C. (1971). Art and culture: critical essays. Boston: Beacon Press.

Kalantzis, M. , \& Cope, B. (2012). New learning: Elements of a science education (2nd ed.).

Cambridge: Cambridge University Press. Supplemented by New Learning: Transformational Designs for Pedagogy and Assessment website. Retrieved from newlearningonline.com Kennedy, K. (2015). Practicing philosophy of childhood: Teaching in the (r)evolutionary mode. Journal of Philosophy in Schools, 2(1), 4-17. Retrieved from

www.ojs.unisa.edu.au/index.php/jps/article/view/1099

Klein, N. (2014). This changes everything: Capitalism vs. the climate. New York: Simon \& Schuster.

Lenhart, A. (2015). Teens, social media, \& technology overview 2015. Washington: Pew Research Centre. Retrieved August 11, 2016, from www.pewlnternet.org/2015/04/09/teenssocial-media-technology-2015/

Lipman, M. (2003). Thinking in education (2nd ed.). Cambridge: Cambridge University Press. MacDonald, D. (1963). Against the American grain. London: Victor Gollanz.

Macintyre, A. (2007). After virtue: A study in moral theory. Notre Dame, IN: University of Notre Dame Press.

Marwick, A. E. (2013). Status update: Celebrity, publicity, and branding in the social media age. New Haven: Yale University Press.

Millett, S. , \& Tapper, A. (2012). Benefits of collaborative philosophical inquiry in schools.

Educational Philosophy and Theory, 44(5), 546-567.

Mulhall, S. (2002). On film. London: Routledge.

Murdoch, I. (1970). The sovereignty of good. London: Routledge.

Nussbaum, M. C. (1987). Finely aware and richly responsible: Literature and the moral imagination. In A. J. Cascardi (Ed.), Literature and the questions of philosophy (pp. 169-191). Baltimore: The John Hopkins University Press. 
Nussbaum, M. C. (1990). Love's knowledge. Oxford: Oxford University Press.

Nussbaum, M. C. (1995). Poetic justice: The literary imagination and public life. Boston: Beacon Press.

Nussbaum, M. C. (2012). The new religious intolerance: Overcoming the politics of fear in an anxious age. Cambridge: The Belknap Press of Harvard University Press.

Sensis Pty Ltd. (2015). Sensis social media report May 2015: How Australian people and businesses are using social media. Melbourne. Retrieved August 11, 2016, from www.sensis.com.au/assets/PDFdirectory/Sensis_Social_Media_Report_2015.pdf

Singer, P. (2002). One World: The Ethics of Globalisation. Melbourne: Text Publishing Company.

Splitter, L. (2011). Identity, citizenship and moral education. Educational Philosophy and Theory, 43(5), 484-505.

Splitter, L. , \& Sharp, A. M. (1995). Teaching for better thinking: The classroom community of inquiry. Melbourne: ACER.

Vansieleghem, N. , \& Kennedy, D. (Eds.). (2012). Philosophy for children in transition: Problems and prospects. The Journal of Philosophy of Education Book Series. West Sussex: WileyBlackwell.

Wartenberg, T. E. (2007). Thinking on screen: Film as philosophy. London: Routledge. Winstanley, C. (2008). Philosophy and the development of critical thinking. In M. Hand \& C. Winstanley (Eds.), Philosophy in schools (pp. 85-95). London: Continuum.

\section{Critical perspectivism}

Adorno, T. W. , \& Horkheimer, M. (1990). The culture industry: Enlightenment as mass deception. In T. W. Adorno \& M. Horkheimer (Eds.), Dialectic of enlightenment. New York: Continuum and also Adorno, T. W. (1991). The culture industry: Selected essays on mass culture ( J. M. Bernstein , Ed.). London: Routledge.

Ciprian, M. (2015). The role of ethical theories in the decision making of Australian animal ethics committees: a multi-method examination. Unpublished PhD Dissertation. The University of Western Australia. Scholar's Centre. Accessible via UWA Research Repository. Retrieved from http://research-repository.uwa.edu.au/

D'Olimpio, L. , \& Teschers, C. (2017). Playing with philosophy: Gestures, performance, P4C and an art of living. Educational Philosophy and Theory, Special Issue 'Aesthetic Education' Ed. Elizabeth Grierson . Retrieved from http://www.tandfonline.com/doi/abs/10.1080/00131857.2017.1294974 Hand, M. (2014). Towards a theory of moral education. Journal of Philosophy of Education, 48(4), 519-532.

Kant, I. (1983). Metaphysical principles of virtue ( J. W. Ellington, trans.). Indianapolis: Hackett. MacIntyre, A. (2008). After virtue. Notre Dame, IN: University of Notre Dame Press.

Marcuse, H. (1965/1969). Repressive tolerance. In R. P. Wolff , B. Moore, Jr. , \& H. Marcuse (Eds.), A critique of pure tolerance. Boston: Beacon Press.

Murdoch, I. (1970). The sovereignty of good. Boston: Routledge \& Kegan Paul.

Nietzsche, F. (1872). The birth of tragedy ( C. P. Fadiman, trans.). New York: Dover.

Nietzsche, F. (1974/1882). The gay science ( W. Kaufmann, trans.). New York: Vintage Books. Nietzsche, F. (1994/1887). On the genealogy of morality ( K. Ansell-Pearson, Ed., \& C. Diethe, trans.). Cambridge: Cambridge University Press.

Nussbaum, M. C. (1990). Love's knowledge. Oxford: Oxford University Press.

Nussbaum, M. C. (1995). Poetic justice: The literary imagination and public life. Boston: Beacon Press.

Nussbaum, M. (1998). The Transfigurations of Intoxication: Nietzsche, Schopenhauer and Dionysus, in Nietzsche, Philosophy and the Arts, by Kemal, Gaskell and Conway (Eds).

Cambridge: Cambridge University Press.

Nussbaum, M. C. (2000). Women and human development: The capabilities approach.

Cambridge: Cambridge University Press. 
Nussbaum, M. C. (2001). Upheavals of thought: The intelligence of emotions. Cambridge: Cambridge University Press.

Noddings, N. (1984). Caring: A feminine approach to ethics and moral education. Berkeley: University of California Press.

Richardson, H. S. (1998). Nussbaum: Love and respect. Metaphilosophy, 24(9), 254-262.

Swanton, C. (2003). Virtue ethics: A pluralistic view. Oxford: Oxford University Press.

Swanton, C. (2015). The virtue ethics of Hume and Nietzsche. Oxford: John Wiley \& Sons. Weil, S. (1978). Lectures on philosophy. Cambridge: Cambridge University Press.

Williams, B. (1973). Problems of the self. Cambridge: Cambridge University Press.

\section{Compassionate engagement}

Aristotle . (1876). The Nicomachean ethics. London: Longmans, Green.

Blum, L. (1987). Compassion. In R. B. Kruschwitz and R. C. Roberts (Eds.), The virtues: Essays on moral character (pp. 229-236). Belmont: Wandsworth.

Carroll, N. (2000). Art and ethical criticism: An overview of recent directions of research. Ethics, 110(2), 350-387.

D'Olimpio, L. , \& Peterson, A. (2017). The ethics of narrative art: Philosophy in schools, compassion and learning from stories. Journal of Philosophy in Schools, 4(2). Special issue 'Why should Philosophy be taught in schools?' Ed. M. Hand.

Hepburn, R. W. (1990). Art, truth and the education of subjectivity. Journal of Philosophy of Education, 24, 185-198.

James, H. (1905). The golden bowl. London: Methuen \& Company.

Kristjansson, K. (2007). Aristotle, emotions, and education. London: Routledge.

Magee, B. (1978). Philosophy and literature: Dialogue with Iris Murdoch. In B. Magee (Ed.), Men of ideas. London: British Broadcasting Corporation.

Murdoch, I. (1970). The sovereignty of good. London: Routledge \& Kegan Paul. Chapter two, 'On "God" and "good".' In M. Warnock (Ed.), (1996). Women philosophers. London: Everyman \& J. M. Dent.

Murdoch, I. (1998). Existentialists and mystics: Writings on philosophy and literature ( P. J. Conradi , Ed.). New York: Allen Lane/The Penguin Press.

Nussbaum, M. C. (1990). Love's knowledge: Essays on philosophy and literature. Oxford: Oxford University Press.

Nussbaum, M. C. (1995). Poetic justice: The literary imagination and public life. Boston: Beacon Press.

Nussbaum, M. C. (1998). Exactly and responsibly: A defence of ethical criticism. Philosophy and Literature, 22, 343-365.

Nussbaum, M. C. (2001). Upheavals of thought: The intelligence of emotions. Cambridge:

Cambridge University Press.

Nussbaum, M. C. (2010). Not for profit: Why democracy needs the humanities. Princeton, NJ: Princeton University Press.

Nussbaum, M. C. (2012). The new religious intolerance: Overcoming the politics of fear in an anxious age. Cambridge: The Belknap Press of Harvard University Press.

Peterson, A. (2016). Compassion and education: Cultivating compassionate children, schools and communities. London: Palgrave Macmillan.

Posner, R. A. (1997). Against ethical criticism. Philosophy and Literature, 21(1), 1-27.

Twain, M. (1884). Adventures of Huckleberry Finn. London: Chatto \& Windus/orig. Charles L. Webster and Company.

Wilde, O. (1891). The picture of Dorian Gray. New York: W.W. Norton \& Company, Inc. Young, J. O. (2005). Aesthetics: Critical concepts in philosophy. London: Routledge. 


\section{Critical engagement}

Adorno, T. W. , \& Benjamin, W. (1999). The complete correspondence 1928-1940 ( H. Lonitz (Ed.) \& N. Walker , trans.). Cambridge: Harvard University Press.

Adorno, T. W. , \& Horkheimer, M. (1997). The culture industry: Enlightenment as mass deception. In T. W. Adorno \& M. Horkheimer (Eds.), Dialectic of enlightenment. London: Verso. Adorno, T. W. (1975). Culture industry reconsidered. New German Critique, 6, 12-19. Adorno, T. W. (1967). Prisms ( S. Weber \& S. Weber, trans.). Cambridge: MIT Press. Adorno, T. W. (1981-1982). Transparencies on film ( T. Y. Levin , trans.). New German Critique, Special Double Issue on New German Cinema 24/25, 199-205.

Badiou, A. (2009). Cinema as a democratic emblem ( A. Ling \& A. Mondon , trans.). Parrhesia, 6: 1-6.

Benjamin, W. (1991-1999). Selected Writings ( H. Eiland \& M. W. Jennings, Eds.). Cambridge: Harvard University Press.

Benjamin, W. (1969). The work of art in the age of mechanical reproduction ( H. Zorn , trans.). In H. Arendt (Ed.), Illuminations (pp. 217-252). New York: Schocken Books.

Brummett, B. (2013). What popular films teach us about values: Locked inside with the Rage Virus. Journal of Popular Film and Television, 41(2): 61-67.

Bloch, E. et al., (1977). Aesthetics and politics ( R. Taylor , trans.). Radical Thinkers Series. London: Verso.

Carroll, N. (2004). The power of movies. In P. Lamarque \& S. H. Olsen (Eds.), Aesthetics and the philosophy of art: The analytic tradition (pp. 485-497). Oxford: Blackwell.

Carroll, N. (1998). A philosophy of mass art. Oxford: Clarendon Press.

Carroll, N. (1988). Art, practice and narrative. Monist, 71(2): 140-156.

Carroll, N. (1994). Identifying art. In R. Yanal (Ed.), Institutions of art. University Park:

Pennsylvania State University Press.

Carroll, N. (1993). Historical narratives and the philosophy of art. Journal of Aesthetics and Art Criticism, 51(3): 313-326.

Chalmers, D. (2016). David Chalmers on Pokémon Go and the future of reality' interviewed on ABC Radio National's 'The Philosopher's Zone'. Retrieved August 19, 2016, from

www.abc.net.au/radionational/programs/philosopherszone/david-chalmers-on-pokemon-go-andthe-future-of-reality/7662524. Accompanied by 'The Value of Virtual Worlds' article 1/8/2016, an edited extract from Chalmers' 'The Virtual and the Real'.

Chaplin, C. Dir. (1936). Modern times. Film.

Collingwood, R. G. (1969). The principles of art. Oxford: Oxford University Press.

Colman, F. (2011). Deleuze \& Cinema: The film concepts. Oxford: Berg Publishers.

Deleuze, G. (1986). Cinema I: The movement-image ( H. Tomlinson and B. Habberjam , trans.). Minneapolis: University of Minnesota Press.

Deleuze, G. (1989). Cinema II: The time-image. Minneapolis: University of Minnesota Press.

Devereaux, M. (1998). Beauty and evil: The case of Leni Riefenstahl's Triumph of the Will'. In J. Levinson (Ed.), Aesthetics and ethics: Essays at the intersection. New York: Cambridge University Press.

Hansen, M. (1981-1982). Introduction to Adorno, 'Transparencies on Film' (1966). New German Critique, Special Double Issue on New German Cinema, 24/25, 186-198.

Levine, M. (2001). Depraved spectators \& impossible audiences: Horror and other pleasures of the cinema. Film and Philosophy, Special Edition on Horror, 5: 63-71.

Levinson, J. (2004). Defining art historically. In P. Lamarque and S. H. Olsen (Eds.), Aesthetics and the philosophy of art: The analytic tradition. Oxford: Blackwell.

Markus, G. (2001). Walter Benjamin or: The commodity as Phantasmagoria. New German Critique, 83: 3-42.

McCann, P. (2008). Race, music, and national identity: Images of Jazz in American fiction, 1920-1960. Delaware: Associated University Press.

Osborne, T. (2008). The structure of modern cultural theory. Manchester: Manchester University Press. 
Osborne, P. , and Charles, M. (2011). Walter Benjamin. In E. N. Zalta (Ed.), The Stanford encyclopedia of philosophy. Retrieved from

http://plato.stanford.edu/archives/spr2011/entries/benjamin/

Oxford Dictionaries. (2016). Oxford: Oxford University Press. Oxford dictionaries press release. Retrieved September 6, 2016, from http://blog.oxforddictionaries.com/press-releases/oxforddictionaries-word-of-the-year-2013/

Riefenstahl, L. (1935). Dir. Triumph of the will. Film.

The Minefield, ABC Radio National. Radio Interview 14 July 2016. Waleed Aly, Scott Stephens and Laura D'Olimpio. Retrieved September 6, 2016, from

www.abc.net.au/radionational/programs/theminefield/first-as-pokemon-then-as-farce/7630046.

Supplemented by 'First as Pokémon, Then as Farce? The Risks of the Modern Culture Industry' opinion piece for ABC Religion and Ethics website by L. D'Olimpio (2016). Retrieved from www.abc.net.au/religion/articles/2016/07/14/4500332.htm

Wartenberg, T. E. (2007). Thinking on screen: Film as philosophy. London: Routledge.

Wartenberg, T. E. (2006). Beyond mere illustration: How films can be philosophy. The Journal of Aesthetics and Art Criticism, 64(1), 19-32.

Weitz, M. (2004). The role of theory in aesthetics. In P. Lamarque and S. H. Olsen (Eds.), Aesthetics and the philosophy of art: The analytic tradition. Oxford: Blackwell.

\section{Social media and multiliteracies}

Alexander, B. , \& Levine, A. (2008). Web 2.0. Storytelling: Emergence of a new genre. A new wave of innovation for teaching and learning. Educause Review, 40-56. Retrieved November 24, 2016, from umwblogs.org Australian Competition and Consumer Commission. Scamwatch. Retrieved from www.scamwatch.gov.au/get-help/real-life-stories.

Chandler, A. (December 15, 2014). The roots of \#IIIRideWithYou: How Monday's hostage crisis in Sydney spawned a social-media movement against anti-Muslim intolerance. The Atlantic. Retrieved April 4, 2017, from www.theatlantic.com/international/archive/2014/12/illridewithyouhashtag-sydney-siege-anti-islam-australia/383765/

Clark, A. , \& Chalmers, D. (1998). The extended mind. Analysis, 58(1), 7-19.

Cope, B. , \& Kalantzis, M. (Eds.). (2000). Multiliteracies: Literacy learning and the design of social futures. London: Routledge.

D'Olimpio, L. (2015). Trust, well-being and the community of philosophical inquiry. He Kupu, 4(2) Special Issue 'Well-being in Early Childhood Education', 45-57.

D'Olimpio, L. (2016). Trust as a virtue in education. Educational Philosophy and Theory, Special Issue 'Trust and Schooling' Ed. Bruce Haynes . DOI: 10.1080/00131857.2016.1194737 http://dx.doi.org/10.1080/00131857.2016.1194737

Edwards, R. , \& Usher, R. (2008). Globalisation and pedagogy: Space, place, and identity (2nd ed.). London: Routledge.

Forgas, J. P. (2007). Why sad is better than happy: Mood effects on the persuasiveness of persuasive messages. Journal of Experimental Social Psychology, 43, 513-528.

Forgas, J. P. (2017, March 31). Why are some people more gullible than others? The Conversation. Retrieved April 4, 2017, from https://theconversation.com/why-are-some-peoplemore-gullible-than-others-72412

Forgas, J. P. , \& East, R. (2008). On being happy and gullible: Mood effects on scepticism and the detection of deception. Journal of Experimental Social Psychology, 44, 1362-1367.

Gee, J. P. (2009). Reflections on reading Cope and Kalantzis' “'Multiliteracies': New Literacies, New Learning". Pedagogies: An International Journal, 4(3): 196-204.

Hoax-Slayer website: www.hoax-slayer.com/

Kahneman, D. (2011). Thinking fast and slow. New York: Farrar, Straus and Giroux.

Marwick, A. E. (2013). Status update: Celebrity, publicity, and branding in the social media age. New Haven: Yale University Press.

McAfee, N. (2015). Acting politically in a digital age. In D. Allen \& J. S. Light (Eds.), From voice to influence: Understanding citizenship in a digital age (pp. 273-292). Chicago: University of Chicago Press. 
McLuhan, M. (1964/1995). Understanding media. Cambridge: MIT Press.

The online Cambridge Dictionary, Cambridge University Press, 2017. Retrieved January 16, 2017, from http://dictionary.cambridge.org/dictionary/english

Preece, P. F. W. , \& Baxter, J. H. (2000). Scepticism and gullibility: The superstitious and pseudo-scientific beliefs of secondary school students. International Journal of Science Education, 22(11), 1147-1156. http://dx.doi.org/10.1080/09500690050166724 04/04/2017 Schulman, Y. (2010). Catfish. DVD. Dir. H. Joost \& A. Schulman . New York City: Supermache. Snopes.com website: www.snopes.com/

Zelnio, K. (March 14, 2012). On Slacktivism: Lessons from \#Kony2012. Scientific American. Retrieved April 5, 2017, from https://blogs.scientificamerican.com/evo-eco-lab/on-slacktavismlessons-from-kony2012/

\section{Teaching critical perspectivism}

Burgh, G. , Field, T. , \& Freakley, M. (2006). Ethics and the community of inquiry: Education for deliberative democracy. Melbourne, Australia: Thomson.

Cam, P. (2006). Twenty thinking tools. Camberwell, Victoria, Australia: ACER. A modified version of the Question Quadrant retrieved from

www.philosophyineducation.com/resources/Question+Quadrant.pdf

Cam, P. (2016). Basic operations in reasoning and conceptual analysis. Journal of Philosophy in Schools, 3(2), 7-18. Retrieved from

www.ojs.unisa.edu.au/index.php/jps/article/view/1347/875

Dewey, J. (1997). How we think. Mineola, NY: Dover Publications. (Original work published 1910).

Dewey, J. (2004). Democracy and education. Mineola, NY: Dover Publications. (Original work published 1916).

Education Endowment Foundation. (2015, July). Philosophy for children: Evaluation report and executive summary. Independent evaluators: Stephen Gorard, Nadia Siddiqui and Beng Huat

See.

Gardner, S. T. (2015). Inquiry is no mere conversation (or discussion or dialogue). Facilitation of inquiry is hard work! Journal of Philosophy in Schools, 2(1), 71-91. Retrieved from

www.ojs.unisa.edu.au/index.php/jps/article/view/1105/777

Golding, C. (2012). Epistemic progress: A construct for understanding and evaluating inquiry. Educational Theory, 62(6), 677-693.

Gorard, S. , Siddiqui, N. , \& See, B. H. (2016). Can 'Philosophy for Children' improve primary school attainment? Journal of Philosophy of Education DOI: 10.1111/1467-9752.12227.

Retrieved January 3, 2017, from http://onlinelibrary.wiley.com/doi/10.1111/1467-

9752.12227/epdf

Hand, M. (2008). Can children be taught philosophy? In M. Hand \& C. Winstanley (Eds.), Philosophy in schools (pp. 3-17). London: Continuum.

Haynes, F. (2014). Editorial. Educational Philosophy and Theory, 46(11), 1197-1202.

Kennedy, D. (2015). Practicing philosophy of childhood: Teaching in the (r)evolutionary mode. Journal of Philosophy in Schools, 2(1), 4-17. Retrieved from

www.ojs.unisa.edu.au/index.php/jps/article/view/1099/772

Lipman, M. (1974). Harry Stottlemeier's discovery. New York: Columbia University Press.

Lipman, M. (1988). Philosophy goes to school. Philadelphia, PA: Temple University Press.

Lipman, M. (2003). Thinking in education (2nd ed.). Cambridge: Cambridge University Press.

Lipman, M. (2004). Philosophy for children's debt to Dewey. Critical and Creative Thinking, 12(1), 1-8.

Matthews, G. (1980). Philosophy and the young child. Cambridge: Harvard University Press. Millett, S. , \& Tapper, A. (2012). Benefits of collaborative philosophical inquiry in schools.

Educational Philosophy and Theory, 44(5), 546-567.

Pritchard, M. (2014). Philosophy for children. In E. N. Zalta (Ed.), The Stanford encyclopedia of philosophy. Retrieved August 11, 2016, from

http://plato.stanford.edu/archives/spr2014/entries/children/ 
Putnam, H. (1995). Pragmatism. Oxford: Blackwell.

Russell, B. (1946). Philosophy for Laymen. Universities Quarterly, 1, 38-49. Reproduced in Unpopular Essays, Chapter 2 (George Allen \& Unwin, 1951).

Sharp, A. M. (2007). The classroom community of inquiry as ritual: How we can cultivate wisdom. Critical and Creative Thinking, 15(1), 3-14.

Siegel, H. (1980). Critical thinking as an educational ideal. The Educational Forum, 45(1), 7-23. DOI: $10.1080 / 00131728009336046$

Siegel, H. (1988). Educating reason: Rationality, critical thinking, and education. London: Routledge.

Splitter, L. (2011). Identity, citizenship and moral education. Educational Philosophy and Theory, 43(5), 484-505.

Splitter, L. (2016). The dispositional ingredients at the heart of questioning and inquiry. Journal of Philosophy in Schools, 3(2), 18-39. Retrieved from www.ojs.unisa.edu.au/index.php/jps/article/view/1348/876

Splitter, L. , \& Sharp, A. M. (1995). Teaching for better thinking: The classroom community of inquiry. Melbourne, Australia: ACER.

Sprod, T. (2001). Philosophical discussion in moral education: The community of ethical inquiry. London: Routledge.

Topping K. J. , \& Trickey, S. (2007a). Collaborative philosophical enquiry for school children: Cognitive gains at two-year follow-up. British Journal of Educational Psychology, 77(4), 787-796.

Topping, K. J. , \& Trickey, S. (2007b). Impact of philosophical enquiry on school students' interactive behaviour. Thinking Skills and Creativity, 2(2), 73-84.

Winstanley, C. (2008). Philosophy and the development of critical thinking. In M. Hand \& C. Winstanley (Eds.), Philosophy in schools (pp. 85-95). London: Continuum.

\section{Philosophy in the public sphere}

APA online: The website for the American Philosophical Association. Retrieved April 22, 2017, from www.apaonline.org/?page $=$ data

Collard, P. (2016). Creativity, culture and education: The international foundation for creative learning. Retrieved October 2, 2016, from www.creativitycultureeducation.org/paul-collard Greene, M. , \& Griffiths, M. (2008). Feminism, philosophy and education: Imagining public spaces. In N. Blake, P. Smeyers , R. D. Smith , \& P. Standish (Eds.), The Blackwell guide to the philosophy of education. Oxford: John Wiley \& Sons.

Herman, D. (2017, January 31). Whatever happened to the public intellectual? New Statesman. Retrieved April 22, 2017, from www.newstatesman.com/culture/books/2017/01/whateverhappened-public-intellectual

Klein, N. (2010). No logo. New York: Picador.

Klein, N. (2014). This changes everything: Capitalism vs. the climate. New York: Simon \& Schuster.

Levmore, S. , \& Nussbaum, M. C. (Eds.). (2010). The offensive Internet: Speech, privacy and reputation. Cambridge: Harvard University Press.

Nussbaum, M. C. (2012). The new religious intolerance: Overcoming the politics of fear in an anxious age. Cambridge: The Belknap Press of Harvard University Press.

Randell, M. (2004). Constructing participation spaces. Community Development Journal, 39(2), 144-155.

Singer, P. (2002). One world: The ethics of globalisation. Melbourne: Text Publishing Company. World Economic Forum. (2016). The 10 skills you need to thrive in the fourth industrial revolution. Written by Gray, A. Retrieved October 22, 2016, from www.weforum.org/agenda/2016/01/the-10-skills-you-need-to-thrive-in-the-fourth-industrialrevolution/ 
